ENTREPRENEURSHIP AND SUSTAINABILITY ISSUES

ISSN 2345-0282 (online) http://jssidoi.org/jesi/

2020 Volume 7 Number 4 (June)

http://doi.org/10.9770/jesi.2020.7.4(14)

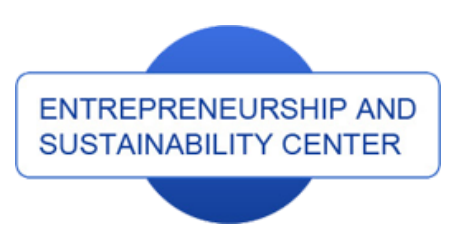

Publisher

http://jssidoi.org/esc/home

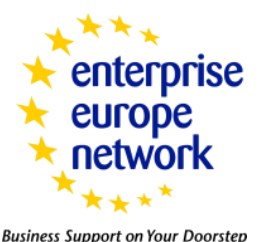

Business Support on Your Doorstep

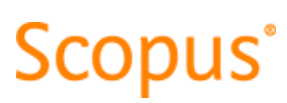

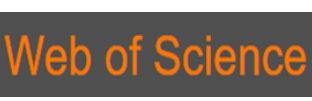

Clarivate
Analytics

\title{
NON-PROFIT SECTOR IN KAZAKHSTAN: INFLUENCE ANALYSIS AND DEVELOPMENT OPPORTUNITIES*
}

\author{
Bagdat Spanova ${ }^{1}$, Gulmira Nakipova ${ }^{2}$, Galina Pestunova ${ }^{3}$, Aigul Mukatay ${ }^{4}$, \\ Baldyrgan Jazykbayeva ${ }^{5}$ \\ 1, 2,5 Karaganda Economic University of Kazpotrebsouz, Akademicheskaya 9 Street, Karaganda, Kazakhstan \\ ${ }^{3,4}$ D. Serikbayev East Kazakhstan state technical university, Ust-Kamenogorsk, Kazakhstan \\ E-mails: ${ }^{1}$ spanova.bagdat@bk.ru; ${ }^{2}$ nakipovage@mail.ru; ${ }^{3} g$ pestunova@mail.ru; ${ }^{4} \underline{19 t a s @ m a i l . r u ;}$ \\ 5 baldirgan_keu@mail.ru
}

Received 16 August 2019; accepted 11 March 2020; published 30 June 2020

\begin{abstract}
The paper describes the analysis and assessment of non-profit sector development drivers in the Republic of Kazakhstan. The authors identify the most significant factors that influence the nonprofit sector on the basis of multifactor correlation and regression analysis. The scale of the non-profit sector is determined on the basis of two indicators: the number of non-profit sector institutions and Global Venture Alliance (GVA). The authors have estimated two analysis options. The first option assesses the effect of the economy on the number of institutions (inflation, government expenditures on the social sphere, actual final consumption) and the effect of the population (employment, income, number of socially vulnerable groups). The most significant factors were income indicators, their correlation with the minimum subsistence level and the number of socially vulnerable groups. The second option considered GVA as a resulting indicator and studied the dependence of the sector's economic results on its potential, and the sector's state support on the population's standard of living and the number of socially vulnerable groups. The influence of the state social contract does not have a positive effect on the sector's GVA volume, which indicates the problem in its priorities and distribution mechanisms. The authors proposed a transition to the consumer subsidy model and infrastructure support for social entrepreneurship development as one of the priority directions of non-profit sector transformation.
\end{abstract}

Keywords: non-profit sector; correlation and regression analysis; influence drivers; consumer subsidies; state social contract

Reference to this paper should be made as follows: Spanova, B., Nakipova, G, Pestunova, G., Mukatay, A., Jazykbayeva, B. 2020. Nonprofit sector in Kzakhstan: influence analysis and development opportunities. Entrepreneurship and Sustainability Issues, 7(4), $2784-2802$. http://doi.org/10.9770/jesi.2020.7.4(14)

JEL Classifications: Z19, L30.

\footnotetext{
* This research was supported by the project, which has received funding from the Science Committee of the Ministry of Education and Science of the Republic of Kazakhstan Social entrepreneurship in modern economic systems: concept, typology, development mechanisms in Kazakhstan. Grant Agreement Number AP05130260
} 


\section{ENTREPRENEURSHIP AND SUSTAINABILITY ISSUES}

ISSN 2345-0282 (online) http://jssidoi.org/jesi/

2020 Volume 7 Number 4 (June)

http://doi.org/10.9770/jesi.2020.7.4(14)

\section{Introduction}

The non-profit sector in the modern economy has many functions. One of the most important ones is the service provision from public sector resources in the social sphere. It is also the basis for the social entrepreneurship development worldwide. Most of the social entrepreneurs identified in Kazakhstan operate through non-nprofit institutions and use their accumulated potential (Pritvorova, Ayaganova, 2017).

At the end of 2018, the number of legal entities registered in Kazakhstan increased by $5.1 \%$ - as of January 1, 2019 , there are about 433.8 thousand of them in the republic. The largest growth is shown by small (up to 424.8 thousand) and large (up to 2488 units) business. The number of operating non-profit organizations amounted to 13184 units (Statistics committee Ministry of National Economy of the Republic of Kazakhstan). The entry of mankind into the era of the global information society, in which information, knowledge and intellectual activity is gradually becoming leading, has led to the emergence and development of the "third sector" of the modern world. Social entrepreneurship inherently plays an important role in society, as it solves certain urgent social problems. If business is purposefully working in order to make money, then social entrepreneurship does not focus on earning, but on solving a social problem, instead.

In the topic of social entrepreneurship, it is necessary, first of all, to realize that it does not concern material wealth, but primarily spiritual wealth. Non-governmental organizations (NGO) already today play a huge role in Kazakhstan in human rights activities, and in realizing the special interests of population groups, and in social stabilization of society.

Analyzing the experience of foreign countries, the author concluded that:

1) in the most countries, in particular, developing (e.g. the Middle East, Central Asia, Russia), the practice of social entrepreneurship is under development;

2) the difference from the focus of social initiatives is different in developed and developing countries;

3) many public sector organizations are still donor-dependent, so raising awareness about social partnerships (SPs) is needed;

4) culture and mentality may be one of the key factors affecting the social sector;

5) the larger the economy is resource-dependent - the higher is civic activity, and, respectively, economic development;

6) in the most countries, social entrepreneurship was created on the basis of existing NGOs;

7) political instability, change of power - more active civic position leads to the search for new solutions;

8) support of international organizations.

Therefore, experience working with various clients from non-profit organizations, including charitable organizations, housing associations, educational institutions and trade unions, has strengthened the understanding of the specific problems inherent in this sector.

The definition of social entrepreneurship in Kazakhstan has not yet been formulated; there is no law on social entrepreneurship. Alas, the focus on identifying and supporting social entrepreneurs has already been done by both public organizations, including international, and government agencies. In 2019, the Ministry of Information and Social Development (MISD) of the Republic of Kazakhstan, together with the Impact Hub Almaty corporate fund, held the first republican Ozgeris ustasy award. 15 of its winners received grants in the amount of 500 thousand tenge, and in addition, the Register of Social Entrepreneurs of Kazakhstan was formed, which included 152 social entrepreneurs of the country. Based on this registry, you can see that:

- the majority (a bit over 40\%) of social entrepreneurs are concentrated in the "assistance / support for vulnerable groups" segment,

- the second largest segment is "education" $(14.85 \%)$. 


\section{ENTREPRENEURSHIP AND SUSTAINABILITY ISSUES}

ISSN 2345-0282 (online) http://jssidoi.org/jesi/

2020 Volume 7 Number 4 (June)

http://doi.org/10.9770/jesi.2020.7.4(14)

- 43.4\% of social entrepreneurs have been operating for more than five years, and the most active regions in this matter are Turkestan region (there are $22 \%$ of those included in the register of social entrepreneurs), Nur-Sultan $(19 \%)$ and only then - Almaty (7\%).

Over 27,000 non-profit organizations are registered in the Republic of Kazakhstan (according to various estimates), which makes up more than $6 \%$ of the total number of legal entities, according to other sources their number is 18,000 . Different statistics are due to different reasons:

1) state statistical accounting in the structure of the third sector includes all organizations listed by the Law of the Republic of Kazakhstan "On Non-Profit Organizations" (Law 2001 “On Non-Profit Organizations”). Meanwhile, some independent research agencies exclude state institutions, bar associations, consumer cooperatives, notarial chambers, etc. from the third sector, which are taken into account by official statistics. Naturally, with this accounting, the number of organizations is reduced by 2 times.

2) most NGOs are inactive (that is, they exist only on paper), which complicates the calculation of really functioning organizations and leads to a distortion of statistics;

3) some cease their activities (more often actually than legally), as a result, new organizations are registered.

Thus, in Kazakhstan, there is an imperfection of statistical accounting of non-governmental organizations.

Public sector resources are considered by modern researchers as a source of non-profit sector's financial stability and potential growth, and permanent income generating activities are considered as a basis for its development based on the type of social entrepreneurship.

The exact size of the nonprofit sector in the world is difficult to assess, but it can be confidently stated that in the countries of Europe and the USA its work has a significant impact on the economy. So, in 2014 in the USA the number of officially registered non-profit organizations amounted to 141,000,000, in 2013 their contribution to the economy amounted to 5.4\%. Despite the effects of the global economic crisis, private donations in the nonprofit sector are increasing. Hence, in the USA since 2013, the volume of receipts from private donors has grown by $7.1 \%$. According to the CAF, which studies charity trends in more than 140 countries, in 2010-2014 in both developed and developing economies, and in transition economies, charitable contributions increased slightly. The non-profit sector plays an important role in the social services provided to the population in modern economies, despite the fact that its activities remain more limited compared to those of the private and public sectors. The share of the non-profit sector in GVA of the developed world varies from 3 to $6 \%$ and tends to be positive (Rozhdestvenskaya, 2017). According to The Johns Hopkins Comparative Nonprofit Sector, the aggregate nonprofit sector is the seventh largest economy in the world, immediately following Great Britain and France and ahead of Italy, Brazil, Russia, Spain and Canada. The world average contribution of NPOs to GDP is 4.5\%. The share of employees is much higher, for example, in Canada - 10.5\%, in the USA - 9\% (Salamon 2014). The domestic non-profit sector is somewhat diverse in terms of the types of activities they practice, since it has about 26 main activities of organizations, of which about 12 activities are primarily social (preschool education, social services, culture, sports and leisure activities, financing, public infrastructure, ecology, and much more).

\section{Research background}

The non-profit sector development and social entrepreneurship was significantly covered within the global community (Lombardo, 2013). The awareness of this phenomenon dates back to the 90s of the 20th century, when both practitioners and academic scholars started addressing new methods of solving social problems. Modern classic scholars include G. Dees (Dees, 2001), R. Martin and S. Osberg (Martin, Osberg, 2007), K. Alter (Alter, 2007), Haugh (Haugh, 2007), Bowlby S., Lloyd Evans S. (Bowlby \& Lloyd Evans, 2011), J. Defornie and J. Nissens, (Defourny, Nyssens, 2010), J. Austin (Austin, 2010), L. Gramescu (Gramescu, 2016), R. Lance (Lance, 2017), L. Racheda (Racheda, 2018), Franco M. \& Haase H. (Franco M. \& Haase, 2017), F. Vigliarolo (Vigliarolo, F. 2020) and many others. In the post-Soviet area, active research is being conducted by A. Moskovskaya and V. Soboleva (Moskovskaya, Soboleva, 2011), Yu. Nesterenko and A. Plyukhina (Nesterenko, Plyukhina, 2017), D. Kachko (Kachko, 2017), A. V. Kuzmin, S. V. Yegerev (Kuzmin, Yegerev, 2009) and others. 


\section{ENTREPRENEURSHIP AND SUSTAINABILITY ISSUES}

ISSN 2345-0282 (online) http://jssidoi.org/jesi/

2020 Volume 7 Number 4 (June)

http://doi.org/10.9770/jesi.2020.7.4(14)

In addition, empirical studies in this sector identify business models of entrepreneurship while maintaining the social mission priority (Gelashvili, Zhumanova, 2019).

The non-profit sector in Kazakhstan is developing with the goal of achieving social, charitable, cultural, educational, legal, health and environmental, sporting goals; to meet religious needs. For example, the annual foreign financing of NGOs is about five billion tenge (13.6 million dollars). Such funding receives about two hundred NGOs, $70 \%$ falls on the United States and international organizations. In Kazakhstan, according to the Ministry of Social Development, 53 international organizations, 30 foreign state organizations, 77 foreign nongovernmental public organizations authorized and registered by the government conduct their activities. 13,6 million dollars (or about 5 billion tenge) are annually allocated by foreign investors to support domestic nonprofit associations, where the key figures are international NGOs and the United States, whose share is $70 \%$ of all foreign financing (Statistics committee Ministry of National Economy of the Republic of Kazakhstan).

So, Bob Doherty, Helen Haugh and Fergus Lyon (2014) analyze on organizations with a social focus, defining organizations' commitment to financial sustainability and solving of social problems. Franco M. and Belo M. (2013) in their publications consider network collaboration as a mechanism for enhancing territorial competitiveness, with an emphasis on social entrepreneurship. Kowo, S. A., Adenuga, O. A. O., Sabitu, O.O. (2019) provide cases when small enterprises help to alleviate povety. Singgalen, Y.A., Sasongko, G., Wiloso, P.G. (2019) analyze partnership between coomunity and bussiness for achieving better results for society.

\section{Materials and methods}

There is a need to find adequate methods for measuring the social effectiveness of NGOs:

1) Calculation of statistical coefficients - involves a comparison of actual indicators with target indicators, where the final indicator may reflect a comparison of planned and actual social results of NGOs or social results and the costs of achieving them.

2) Dynamic methods - based on the determination of net cash flows that are capable of generating certain social consequences of NPO activities.

3) Methods of correlation and regression analysis - involve the determination of the tightness or type of connection between the social results of the activities of NPOs and their costs.

4) Optimization methods - based on the definition of the boundaries of production capabilities and the efficiency indicator as a measure of the remoteness of a particular NPO from it.

5) The method of "factorial survey" is one of the universal methods, using which a set of evaluation criteria for the analyzed NPOs is compiled, after which a random sample of combinations of values of the corresponding criteria is formed. The involved experts give each of the sets of target values included in the sample an aggregated quantitative assessment in a certain scale, after which the methods of regression analysis calculate the weights of individual criteria that best approximate the data by the assessment experts and use the found weights to compile an aggregated performance criterion.

A non-profit institution may perform one or several types of activities stipulated by the laws of the Republic of Kazakhstan and relevant to the goals of the non-profit institution as stipulated by its constituent documents.

Legislative acts of the Republic of Kazakhstan may impose restrictions on the types of activities that non-profit institutions of certain organizational and legal forms are entitled to conduct.

Non-profit institutions are regulated by the Law of the Republic of Kazakhstan On Non-profit Institutions and other regulatory legal acts in force in the territory of the Republic of Kazakhstan (Law 2001 "On Non-Profit Organizations").

Thus, in accordance with the requirements of the Law of the Republic of Kazakhstan On Non-profit Institutions, non-profit institutions are:

1. Institutions and private institutions. 


\section{ENTREPRENEURSHIP AND SUSTAINABILITY ISSUES}

ISSN 2345-0282 (online) http://jssidoi.org/jesi/

2020 Volume 7 Number 4 (June)

http://doi.org/10.9770/jesi.2020.7.4(14)

2. Private associations

3. Fund

4. Consumer cooperative

5. Religious organization

6. Other legal form of non-profit organization

7. Association of legal entities in the forms of association (union).

The activity of non-profit institutions is an integral part of economic and social progress, which, on its part, contributes to the solution of such problems as population employment, material and spiritual well-being of the population, national projects implementation, rational use of free time and a certain level of quality of life.

Non-profit institutions can be established to achieve:

- social, cultural, scientific, educational, charitable and management goals;

- protection of the rights and legal interests of citizens and institutions;

- resolution of disputes and conflicts;

- satisfaction of spiritual and other needs of citizens;

- protection of citizens' health, environmental protection, development of physical culture and sports;

- provision of legal assistance, as well as for other purposes aimed at ensuring public goods and benefits of its members (participants) (Mersiyanova, 2017).

Non-profit institutions may be established in the form of an institution, public association, joint-stock company, consumer cooperative, fund, religious organization, association of legal entities as an association (union) and in any other form provided by laws.

Non-profit sector is the sector involved by the social state to implement its main function: social benefits generation in the public sector of the economy. The right to produce social benefits with an individual character of assigning a social effect and a significant secondary effect at the macro-level at the same time was granted to the non-profit sector for the purpose of optimizing state budget expenditures (Rubinstein, 2009).

In the second half of the 20th century, the growing attention of the world community to the issues of inclusive development of the society and the social equity implementation not only activated the discussion in theory and practice, but also caused the challenge to diversify the service providers in the conditions of demand individualization for public goods (Sen, 2016). The non-profit sector of the economy, with its ability to meet individual needs at a lower cost than the public sector, has become the main provider of public social services in some countries. The researchers note that in the United States, for example, in addition to hundreds of community institutions, it includes $90 \%$ of day care centers, $46 \%$ of primary and secondary schools, $50 \%$ of colleges and universities, $2 / 3$ of social service centers, more than $60 \%$ of clinics and hospital complexes and other institutions of the "non-market services sector" (Schlichter, 2016).

Official data show that the contribution of the non-profit sector to the country's GDP in 2016 was $7.6 \%$ in the U.S., 2.7\% in New Zealand, 3.8\% in Australia, etc (Rozhdestvenskaya, 2017). In Kazakhstan, this number was $3.4 \%$ in 2017, which makes it possible to consider the sector of non-profit institutions to be quite comparable with other countries (National accounts of the Republic of Kazakhstan, 2019).

In recent years, most have been directed to the social sphere. In 2019, 4.8 trillion tenge, or $45 \%$ of the budget, was allocated for the social sector, including three trillion for social assistance, 1.1 trillion for health care, 583 billion for education, 78 billion tenge for culture and sports ". Within the framework of these funds it is planned:

- Strengthening social support for certain categories of citizens - 224.3 billion tenge;

- the construction of rental housing for low-income large families and the introduction of soft loans through Zhilstroy Sber Bank - 100 billion; 


\section{ENTREPRENEURSHIP AND SUSTAINABILITY ISSUES}

ISSN 2345-0282 (online) http://jssidoi.org/jesi/

2020 Volume 7 Number 4 (June)

http://doi.org/10.9770/jesi.2020.7.4(14)

- development of regional infrastructure - 90 billion;

- implementation of the special project "Auyl - El Besigi" - 30 billion tenge.

According to the Ministry of the Republic of Kazakhstan, out of 224.3 billion tenge aimed at strengthening support for hotel categories of citizens, specifically, 49.6 billion tenge will be allocated for targeted social assistance in 2019, 115 billion in 2020, 108 in 2021 billion tenge. With an increase in disability benefits by 30\% this year, 5 billion tenge will be allocated, in 2020 - 12.8 billion, in 2021 - 14.9 billion tenge. To increase the wages of low-paid budget workers this year - 169.7 billion tenge, for 2020 - 397 billion, for the 2021 st - 410 billion tenge.Diversification of non-profit sector funding sources in many countries at the expense of not only public resources, but also private and corporate funds, foreign and international institutions ensured a stable financial base for the non-profit sector (Statistics committee Ministry of National Economy of the Republic of Kazakhstan). Ultimately, it is their own commercial revenues that allowed the nonprofit sector (hereinafter referred to as NPOs) to generate an independent financial platform (Salamon, Anheier, 2014). The current stage of the non-profit sector (hereinafter referred to as NPS) development differs in the fact that it includes the phenomenon of social entrepreneurship, which combines a social mission with various sources of income, which ensures the subject's financial stability (grants, subsidies) and provides an opportunity to receive permanent income associated with activities in the market (Thompson, Doherty, 2012; Gramescu, 2016).

Moreover, these revenues are distributed only in part or not distributed at all, but are directed to the social mission or organization's development as a business entity. Social entrepreneurship is described by many scholars as the fourth sector of the economy that combines the characteristics of all three sectors (public, private and nonprofit) (Newey, 2017; Rasheda, 2018).

This paper aims to analyze the factors of non-profit sector development and suggest ways to expand its development opportunities. The research method is a multifactor correlation-regression analysis, which enables us to assess the interrelation and influence of many factors on the result indicator (Yeliseeva, Yuzbashev, 2012).

\section{Results and Discussion}

Today, the non-profit sector is a serious "player" in the global economy. This is confirmed by the real achievements in the economy and social sphere that NGOs demonstrate. Describing the contribution of NPOs to the economy, we note:

1) Direct contribution of the non-profit sector to the economy:

- ensuring employment and self-employment of the population;

- providing socio-psychological support to the socially vulnerable part of the population involved in economic activity;

- purchase and production of goods necessary for the activities of NPOs,

- stimulation of aggregate demand (theory of demand for NPO products) and aggregate supply (theory of supply based on the form of managing);

- NPOs work in niches that, given the natural state of affairs in a free and competitive market, would not interest the commercial sector, since they give too small profit margins.

2) Indirect contribution of the non-profit sector to the economy:

- NPOs introduce elements of competition into the social sphere, increasing the efficiency of the functioning of the system of providing social services;

- the possibility of reducing the tax burden;

- the activities of NGOs help to improve the level of education and health of the nation, which increases the efficiency of the economy and ensures higher rates of economic growth;

- social and political stability, which are necessary conditions for economic growth.

According to a survey conducted within the framework of the project "I-SEED: Social Entrepreneurship and 


\section{ENTREPRENEURSHIP AND SUSTAINABILITY ISSUES}

ISSN 2345-0282 (online) http://jssidoi.org/jesi/

2020 Volume 7 Number 4 (June)

http://doi.org/10.9770/jesi.2020.7.4(14)

Education", implemented by the British Council in conjunction with Chevron on the state of social entrepreneurship in Kazakhstan, it was found that the main problem of social entrepreneurship in Kazakhstan was the lack of information on this topic and low public awareness of the concept of social entrepreneurship.

We note some problems in the field of social protection of the population (Table 1).

Table 1. Problems in the field of social protection

\begin{tabular}{|c|c|c|}
\hline № & Problem & Description / Recommendations \\
\hline 1 & $\begin{array}{l}\text { Inconsistency of established insurance } \\
\text { tariffs and assignment of types of economic } \\
\text { activity to occupational risk classes }\end{array}$ & $\begin{array}{l}\text { Conduct a study to substantiate the correctness of the calculation of the } \\
\text { establishment of insurance tariffs with the participation of NPP and initiate the } \\
\text { introduction of appropriate amendments to the Law of the Republic of Kazakhstan } \\
\text { dated February 7, } 2005 \text { No. } 30 \text { "On compulsory insurance of an employee against } \\
\text { accidents in the performance of his labor (official) duties" (Law, 2005) }\end{array}$ \\
\hline 2 & $\begin{array}{l}\text { Combining social payments into one type } \\
\text { of payment }\end{array}$ & $\begin{array}{l}\text { The current mechanism for retaining and calculating data on social payments is very } \\
\text { complicated and difficult to understand today. For each social payment instructions, } \\
\text { instructions, rules. The object of taxation for all these types of social payments is the } \\
\text { wage fund. Combining these social payments into one type of payment for } \\
\text { calculation and payment, with their subsequent breakdown by the necessary funds, } \\
\text { will simplify the current situation. }\end{array}$ \\
\hline 3 & $\begin{array}{l}\text { Remove the administrative barrier } \\
\text { established by paragraph } 7 \text { of Art. } 30 \text { of the } \\
\text { Law of the Republic of Kazakhstan dated } \\
\text { May 4, 2010 No. 274-IV "On Protection of } \\
\text { Consumer Rights" (Law, 2010) }\end{array}$ & $\begin{array}{l}\text { So, upon termination of the contract, settlements with the consumer are made in the } \\
\text { event of a price increase for the product based on its price at the time of termination } \\
\text { of the contract, and in the case of a price reduction based on the price of the product } \\
\text { at the time of purchase. In this connection, it is necessary to amend the current } \\
\text { legislation. }\end{array}$ \\
\hline 4 & $\begin{array}{l}\text { Eliminate the impossibility of } \\
\text { implementing the Law of the Republic of } \\
\text { Kazakhstan "On the Protection of Children } \\
\text { from Information Harmful to Their Health } \\
\text { and Development" }\end{array}$ & $\begin{array}{l}\text { On January 10, 2019, the Law of the Republic of Kazakhstan dated July 2, } 2018 \text { No. } \\
\text { 169-VI "On the Protection of Children from Information Harmful to Their Health } \\
\text { and Development" (Law, 2018) entered into force. According to this Law, } \\
\text { information products at the time of distribution must contain age category. It is } \\
\text { necessary to make amendments to Article } 15 \text { of the Law of the Republic of } \\
\text { Kazakhstan dated July 2, } 2018 \text { No. 169-VI "On the Protection of Children from } \\
\text { Information harmful to their Health and Development." Get a delay in fulfilling the } \\
\text { requirements for the sign of the age category of information products. }\end{array}$ \\
\hline 5 & $\begin{array}{l}\text { Set criteria, standards or rules for } \\
\text { determining the degree of guilt as a } \\
\text { percentage of the employer and employee } \\
\text { in the investigation of an accident }\end{array}$ & $\begin{array}{l}\text { It is necessary to provide in the Labor Code the procedure for determining the degree } \\
\text { of guilt of the employer and employee as a percentage in the investigation of an } \\
\text { accident, or develop an additional regulatory legal act regulating the application of } \\
\text { paragraph } 3 \text { of Art. } 326 \text { Labor Code (2016). }\end{array}$ \\
\hline
\end{tabular}

Based on the identified problems in the field of social protection for the further development of social entrepreneurship in Kazakhstan, the need for:

- to increase the general civic culture of society and instill social responsibility for schoolchildren and youth;

- to disseminate success stories of Kazakhstan's social entrepreneurs who have created sustainable business;

- more widely cover issues and problems of social entrepreneurship in the media, raising awareness;

- to develop educational courses and trainings on social entrepreneurship;

- to improve the relevant legislative framework on social entrepreneurship;

- job creation for vulnerable people;

- development of educational and health services.

We developed two options of correlation-regression analysis:

Option 1: the number of active NPO subjects acts as a dependent variable (a result indicator), the dependence of the sector's scale on the standard of living of the population and the number of socially vulnerable groups was studied.

Option 2: the GVA served as a dependent variable (effective indicator) in the sector of non-profit institutions serving households (NPISH) and the dependence of the sector economic results on its potential, government support, population's standard of living and the number of socially vulnerable groups has been studied. 


\section{ENTREPRENEURSHIP AND SUSTAINABILITY ISSUES}

ISSN 2345-0282 (online) http://jssidoi.org/jesi/

2020 Volume 7 Number 4 (June)

http://doi.org/10.9770/jesi.2020.7.4(14)

\section{Option 1.}

The following parameters were selected for analysis:

- $\quad$ Y (dependent variable) - number of active NPO subjects (except for parties, religious institutions, trade unions);

- $\quad$ X0 - number of population, people;

- $\quad$ X1 - number of pensioners, people;

- $\quad$ X2 - number of state social age-based benefits recipients, people;

- $\quad \mathrm{X} 3$ - number of state social disability benefits recipients, people;

- $\quad$ X3 - number of recipients of state social benefits;

- $\quad$ X4 - number of recipients of state social benefits for loss of breadwinner, people;

- $\quad$ X5 - number of GACP (Targeted State Social Assistance) recipients, persons;

- $\quad$ X6 - household income used for consumption, on average per capita per month, KZT;

- $\quad$ X7 - ratio of income used for consumption and minimum subsistence level, \%;

- $\quad$ X8 - share of population with incomes below the minimum subsistence level, \%;

- $\quad$ X9 - expenditures on actual final consumption of households (from SNA), KZT thous. per capita;

- $\quad \mathrm{X} 10$ - index of household final consumption expenditure, as a percentage of the previous year;

- $\quad$ X11 - GDP per capita, USD per capita

- $\quad \mathrm{X} 12$ - share of government spending on SB (social benefits) and SA (social assistance), as percentage to

GDP;

- $\quad$ X13 - share of public expenditures on education, as percentage to GDP;

- $\quad$ X14 - share of public expenditures on healthcare, as percentage to GDP;

- $\quad$ X15 - consumer price index, \%;

- $\quad$ X16 - consumer price index for services, \%;

- $\quad$ X17 - unemployment rate, \%;

- $\quad$ X18 - number of self-employed people, thous. people.

Further, to build the final model, a package of Microsoft Office applications was used, which enabled us to obtain a correlation matrix, elements of dispersion analysis and balances.

Correlation matrix allows us to obtain a list of factors that directly influence Y, and to exclude those that cannot be used to build an econometric model of the analyzed set of parameters.

The analyzed $\mathrm{Y}$ is "the number of active subjects of NPOs (except for parties, religious institutions, trade unions)" are actually influenced by only six factors, correlation coefficient of the five of which (X0, X1, X3, X6, X9) exceeds $90 \%$. Consequently, they will be included in the model. Also, in our opinion, it is advisable to include parameter X7, even though its correlation coefficient is less than $75 \%$. We believe that it can influence the future econometric model, being an important macroeconomic indicator.

Correlation coefficients of the remaining indicators are negative, which indicates the lack of correlation between them and the key analysis value (Y).

The selected values with a significant correlation coefficient are presented in table 2 . 
Table 2. Selected values (based on the obtained correlation coefficients) for econometric model construction

\begin{tabular}{|l|c|}
\hline \multicolumn{1}{|c|}{ Indicator } & Correlation Coefficient \\
\hline X0 - number of population, people & 0.97 \\
\hline X1 - number of pensioners, people & 0.99 \\
\hline X3 - number of state social disability benefits recipients, people & 0.91 \\
\hline $\begin{array}{l}\text { X6 - household income used for consumption, on average per capita } \\
\text { per month, KZT; }\end{array}$ & 0.95 \\
\hline $\begin{array}{l}\text { X7 - ratio of income used for consumption and minimum subsistence } \\
\text { level, \%; }\end{array}$ & 0.70 \\
\hline $\begin{array}{l}\text { X9 - expenditures on actual final consumption of households (from } \\
\text { SNA), KZT thous. per capita; }\end{array}$ & 0.97 \\
\hline Note: Calculated by the authors. & \\
\hline
\end{tabular}

Source: compiled by authors

Of the aggregated indicators presented in table 1, the first three indicators (X0, X1, X3) represent the characteristics of the country's population, including its socially vulnerable groups. Indicators X6, X7, X9 are indicators of the country's population income, including the poverty indicator, calculated on the basis correlation between the average per capita income used for consumption and the minimum subsistence level.

Using the Data Analysis add-on, we calculated the indicators of the future regression model (table 3).

Table 3. Regression statistics

\begin{tabular}{|l|c|}
\hline \multicolumn{1}{|c|}{ Parameter } & Indicator \\
\hline \multicolumn{1}{|c|}{ Regression statistics } \\
\hline Multiple R & 0.996589759 \\
\hline R-square (determination coefficient) & 0.993191148 \\
\hline Standardized R-square (reduced determination factor) & 0.979573443 \\
\hline Observations & 10 \\
\hline \multicolumn{1}{|c|}{ Co-efficient } \\
\hline Y-intersection & -20571.02 \\
\hline X1 (X0) variable: "population, people" & 0.00083 \\
\hline X2 (X1) variable: "number of pension recipients, people” & 0.011 \\
\hline $\begin{array}{l}\text { X3 (X3) variable: "number of state social disability benefits } \\
\text { recipients, people" }\end{array}$ & 0.00082 \\
\hline $\begin{array}{l}\text { X4 (X6) variable: "household income used for consumption, on } \\
\text { average per capita per month, KZT"; }\end{array}$ & 0.045 \\
\hline $\begin{array}{l}\text { X5 (X7) variable: "ratio of income used for consumption and } \\
\text { minimum subsistence level, \%"; }\end{array}$ & -12.86 \\
\hline $\begin{array}{l}\text { X6 (X9) variable: expenditures on actual final consumption of } \\
\text { households (from SNA), KZT thous. per capita; }\end{array}$ & -2.86 \\
\hline
\end{tabular}

Source: compiled by authors

Table 3 shows that the given coefficient of determination exceeds 99\%, which indicates that the model is consistent with the data; such a model is considered valid.

The final model view is as follows:

$y=-20571.02+0,00083 x_{1}+0.011 x_{2}+0.00082 x_{3}+0.045 x_{4}-12.86 x_{5}-2.86 x_{6}$ 
An important step is to check the obtained model for autocorrelation. We used the Darbin-Watson criterion method which is considered as the best one.

Firstly, we show the calculated balances, and then, using formula, calculate the Darbin-Watson coefficient and the calculated balances (table 4):

$$
D W=\frac{\sum\left(e_{i}-e_{i-1}\right)}{\sum e_{i}^{2}},
$$

where: $e_{i}=y-y(x)$

Table 4. Calculated Balances

\begin{tabular}{|c|c|c|c|c|}
\hline Observation & Predicted Y & Balances & $\left(e_{i}-e_{i-1}\right)$ & $e_{i}^{2}$ \\
\hline 1 & 7984.519775 & -122.5197754 & - & - \\
\hline 2 & 8241.843286 & 99.15671402 & 9832,053935 & 49140,46597 \\
\hline 3 & 8379.860775 & 111.1392248 & 12351,92728 & 143,5805641 \\
\hline 4 & 8894.799371 & -45.79937109 & 2097,582392 & 24629,72287 \\
\hline 5 & 9083.450998 & 131.5490022 & 17305,13997 & 31452,44549 \\
\hline 6 & 9851.786128 & 48.21387183 & 2324,577437 & 6944,743947 \\
\hline 7 & 10636.54616 & -307.5461571 & 94584,63875 & 126565,1982 \\
\hline 8 & 11191.71488 & -102.7148812 & 10550,34681 & 41955,8516 \\
\hline 9 & 11935.86819 & 66.13180801 & 4373,41603 & 28509,20445 \\
\hline 10 & 13061.61044 & 122.389564 & 14979,20537 & 3164,935107 \\
\hline \multicolumn{5}{|c|}{ Total } \\
\hline
\end{tabular}

Source: compiled by authors

Thus, the Darbin-Watson coefficient in our case is 1.86 :

$$
D W=\frac{312506.1482}{168398.888}=1.86
$$

It is generally accepted that if the obtained coefficient is in the range of $1.5<\mathrm{DW}<2.5$, the autocorrelation is not possible. Therefore, the constructed econometric model is effective and can be used in further research on social entrepreneurship development potential in Kazakhstan.

Results. To summarize the research using the correlation-regression model (1 option), we can draw the following conclusions:

The model tested 19 indicators that can potentially influence the scale of the NPISH sector, one of the characteristics of which is the number of NPOs in the country. Six indicators characterize the size and composition of the country's population in terms of socially vulnerable groups. 


\section{ENTREPRENEURSHIP AND SUSTAINABILITY ISSUES}

ISSN 2345-0282 (online) http://jssidoi.org/jesi/

2020 Volume 7 Number 4 (June)

http://doi.org/10.9770/jesi.2020.7.4(14)

Six indicators characterize the standard of living of the population in the country on the basis of income measured at the micro- and macro-level (SNA) and the total welfare indicator as GDP per capita.

Three indicators characterize public policy in the form of public expenditure on education, health, social security and social assistance.

Two indicators characterize the real purchasing power of revenues based on the consumer price index for goods and services.

The two indicators characterize the population employment and highlight the part of the population that is selfemployed and unemployed as a potentially vulnerable group.

As per the matrix of correlation coefficients, 6 indicators were selected, which have a significant impact on the NPC scale, measured by "number of non-profit institutions" factor.

There is a significant correlation between the number of NPOs and the population characteristics: the population number, the number of pension recipients, the number of disability benefits recipients.

A significant relationship exists between the indicators of the population' standard of living at the macro- and micro-level:

- $\quad$ expenditures on actual final consumption of households in KZT thous. per capita (measured at the macro level in system of national accounts);

- $\quad$ household revenues used for consumption, average per capita, KZT;

- $\quad$ the ratio of household revenues used for consumption and the minimum subsistence level.

In accordance with the coefficients signs in the multiple regression equation, the increase of expenditures on final consumption at the macro-level and improvement of the ratio of revenues used for consumption and the minimum subsistence level slightly reduces the society's demand for non-profit institutions. All other factors influence the growth of such demand.

Whereas the minimum subsistence level over the period under consideration has been repeatedly criticized by the scientific community for being too low, the trend towards an increase in the ratio recorded by statistics can be considered an overestimate, not entirely realistic.

As for the expenditures on the actual final consumption of households at the macro-level, they include government expenditures on individual benefits, and the increase in this indicator slightly reduces the population's need for services of non-profit institutions.

Option 2

We used the following indicators for analysis:

- Y (dependent variable) - gross value added in NPISH sector, KZT mln;

- X1 - (active) NPOs number, units;

- X2 - state social contract, KZT mln;

- X3 - number of state social disability benefits recipients, people;

- X3 - number of recipients of state social benefits;

- X4 - number of recipients of state social benefits for loss of breadwinner, people;

- X5 - number of TSSA (Targeted State Social Assistance) recipients, persons;

- X6 - household income used for consumption, on average per capita per month, KZT;

- X7 - ratio of income used for consumption and minimum subsistence level, \%;

- X8 - share of population with incomes below the minimum subsistence level, \%;

- X9 - expenditures on actual final consumption of households (from SNA), KZT thous. per capita;

- X10 - index of household final consumption expenditure, as a percentage of the previous year; 
- X11 - GDP per capita, USD per capita;

- X12 - expenditures on actual final consumption of households (from SNA), KZT thous. per capita;

- X13 - index of household final consumption expenditure, as a percentage of the previous year;

- X14 - GDP per capita, USD per capita

- X15 - share of government spending on SB (social benefits) and SA (social assistance), as percentage to GDP;

- X16 - share of public expenditures on education, as percentage to GDP;

- X17 - share of public expenditures on healthcare, as percentage to GDP;

- X18 - consumer price index, \%;

- X19 - consumer price index for services, \%;

- X20 - unemployment rate, \%;

- X21 - number of self-employed people, thous people.

Further, to build the final model, a package of Microsoft Office applications was used, which enabled us to obtain a correlation matrix, elements of dispersion analysis and balances.

Correlation matrix allows us to obtain a list of factors that directly influence $\mathrm{Y}$, and to exclude those that cannot be used to build an econometric model of the analyzed set of parameters.

The analyzed $\mathrm{Y}$ is "gross value added, KZT mln" is actually influenced by only six factors, correlation coefficient of the six of which $(\mathrm{X} 1, \mathrm{X} 3, \mathrm{X} 4, \mathrm{X} 6, \mathrm{X} 9, \mathrm{X} 12)$ exceeds $90 \%$ which meets the selection criteria. Consequently, they will be included in the model.

Correlation coefficients of the remaining indicators are negative, which indicates the lack of correlation between them and the key analysis value (Y).

Table 5 contains indicators with significant correlation coefficient.

Table 5. Selected values (based on the obtained correlation coefficients) for econometric model construction.

\begin{tabular}{|l|c|}
\hline \multicolumn{1}{|c|}{ Indicator } & $\begin{array}{c}\text { Correlation co-efficient } \\
\text { value, } \%\end{array}$ \\
\hline X1 - number of NPOs (active), units & 0.91 \\
\hline X2 - state social contract, KZT million & 0.8 \\
\hline X3 - population, people & 0.97 \\
\hline X4 - number of pensioners, people & 0.94 \\
\hline X6 - number of state social disability benefits recipients, people & 0.94 \\
\hline $\begin{array}{l}\text { X9 - household revenues used for consumption (average per capita per month), } \\
\text { KZT }\end{array}$ & 0.96 \\
\hline X10 - ratio of income used for consumption and minimum subsistence level, \% & 0.83 \\
\hline $\begin{array}{l}\text { X12 - expenditures on actual final consumption of households (from SNA), } \\
\text { KZT thous. per capita; }\end{array}$ & 0.96 \\
\hline
\end{tabular}

Source: compiled by authors 
Using the "Data analysis" add-in, calculate the future regression model (table 6).

Table 6. Regression Statistics

\begin{tabular}{|c|c|}
\hline Parameter & Indicator \\
\hline \multicolumn{2}{|l|}{ Regression statistics } \\
\hline Multiple R & 0.999832608 \\
\hline R-square (determination coefficient) & 0.999665245 \\
\hline Standardized R-square (reduced determination factor) & 0.996987204 \\
\hline Observations & 10 \\
\hline \multicolumn{2}{|l|}{ Co-efficient } \\
\hline Y-intersection & -5415789.79 \\
\hline X1 variable - "number of NPOs (active), pcs." (X1) & -9.39 \\
\hline $\mathrm{X} 2$ variable - "state social contract, $\mathrm{KZT}$ mln" (X2) & 0.95 \\
\hline $\mathrm{X} 3$ variable - "population, people" (X3) & 0.33 \\
\hline $\mathrm{X} 4$ variable - "number of pensioners, people (X4) & 0.99 \\
\hline X5 variable - "number of state social disability benefit recipients, people" (X6) & 0.007 \\
\hline $\begin{array}{l}\text { X6 variable - "household revenues used for consumption (average per capita per } \\
\text { month), KZT" (X9) }\end{array}$ & 0.26 \\
\hline $\begin{array}{l}\text { X7 variable - "ratio of income used for consumption to the minimum subsistence } \\
\text { level" \% (X10) }\end{array}$ & -1100.56 \\
\hline $\begin{array}{l}\text { X8 variable - "expenditures on actual final consumption of households (from CHC), } \\
\text { KZT thous. per capita" (X12) }\end{array}$ & -352.02 \\
\hline
\end{tabular}

Source: compiled by authors

Table 5 shows that the given coefficient of determination exceeds 99\%, which indicates that the model is consistent with the data; such a model is considered valid.

The final model is as follows:

$$
y=-5415789.79-9.39 x_{1}+0.95 x_{2}+0.33 x_{3}+0.99 x_{4}+0.007 x_{5}+0.26 x_{6}-1100.56 x_{7}-352.02 x_{8}
$$

An important step is to check the obtained model for autocorrelation. We used the most optimal Darbin-Watson criterion.

Firstly, we show the balances that we received in calculation, and then calculate the Darbin-Watson factor and the balances obtained in calculations (table 7). 
Table 7. Balances obtained in calculations

\begin{tabular}{|c|c|c|c|c|}
\hline Observation & Predicted Y & Balances & $\left(e_{i}-e_{i-1}\right)$ & $e_{i}^{2}$ \\
\hline 1 & 81440.89496 & 253.2050385 & - & - \\
\hline 2 & 94150.23771 & 1032.962289 & 1067011,091 & 608021,3699 \\
\hline 3 & 116993.0756 & -1018.945604 & 1038250,144 & 4210326,002 \\
\hline 4 & 148805.4376 & -2821.937607 & 7963331,856 & 3250780,162 \\
\hline 5 & 164611.7324 & 1618.367567 & 2619113,581 & 19716310,03 \\
\hline 6 & 178582.6751 & 988.7248865 & 977576,9012 & 396449,9047 \\
\hline 7 & 259904.9298 & 947.1702108 & 897131,4082 & 1726,791075 \\
\hline 8 & 272974.5667 & 125.2332659 & 15683,37089 & 675580,3413 \\
\hline 9 & 268911.4506 & -1668.350575 & 2783393,641 & 3216942,994 \\
\hline 10 & 269627.9295 & 543.5705282 & 295468,9191 & 4892594,966 \\
\hline
\end{tabular}

Source: compiled by authors

Thus, the Darbin-Watson criterion in our case is 2.09:

$$
D W=\frac{36968732.56}{17656960.91}=2.09
$$

It is generally accepted that if the obtained coefficient is in the range of $1.5<\mathrm{DW}<2.5$, the autocorrelation is not possible. Therefore, the constructed econometric model is effective and can be used in further research on the potential of social entrepreneurship development in Kazakhstan.

Results. The results obtained using the correlation-regression model (Option2) can be estimated as follows.

The model tested 21 indicators, each of which can potentially contribute to the economic results of the NPISH sector, measured as Gross Value Added of NPISH sector. The group of indicators is similar to Option 1, and "Number of operating non-profit institutions, units" and "State social order, million tenge" added.

Significant factors in the model are:

- In terms of economy and the state: number of operating NPOs $(0.91 \%)$, volume of the state social order in million tenge $(0.8 \%)$;

- In terms of population: population $(0.97 \%)$, number of recipients of pensions and state social disability benefits $(0.94 \%)$;

- In terms of standard of living: household revenues used for consumption (average per capita per month) in tenge (96 per cent), the ratio of income used for consumption to the minimum subsistence level in per cent (83 per cent), expenditure on actual final consumption of households in the account of the expendable income of the SNA in thousand tenge per capita (96 per cent).

The final econometric model taking into account the signs in coefficients leads to a paradoxical conclusion that the increase in the number of non-profit institutions reduces the gross value added of the non-profit sector. Each newly established institution within the period under review reduces the GVA volume by 9.3 million tenge. In our opinion, this indicates that during the period under review there was a practice of opening non-profit institutions under a specific grant and these institutions did not carry out any activities other than spending grant money. As a result, the allocated funds were redistributed among a larger number of institutions, which, if no other activities were carried out, had a negative impact on the sector's GVA. As a result, the GVA per organization decreased. It 
is possible that the new practice of NPO registration and the tracking of its history before the allocation of the state grant will have a positive impact on these processes. However, since the model uses data for a long past period, it is not feasible to track and assess the impact of the practice of NPO registration with a special state body at this stage of the study. In addition, we can conclude that the allocation of one additional million tenge to the state social order led to a decrease in NPO activity as a social entrepreneur, reduced incentives to run business in the open market, which in turn reduced the sector's GVA per organization.

The other indicators demonstrated an impact on GVA similar to the first model. In fact, the size of the population and its socially vulnerable groups, especially pensioners and disabled people, has a positive impact on the sector's GVA, which is an obvious fact. The improvement of the income used for consumption and the minimum subsistence level reduces the need of households for the services of non-profit institutions, as they increase their purchasing power and can purchase services in the open market. Therefore, the factor has a negative effect on the sector's GVA. The increase in expenditures on the actual final consumption of households in the account of the use of disposable income of the SNA reduces the Gross Domestic Product Value (GDP) of the sector, because it is accompanied by the free of charge allocation of social services for the population at the macro-level, as natural transfers of the state for individual consumption by the population. This reduces the population's demand for nonprofit institutions services.

The final consumption of households consists of many components and it is difficult to influence its size directly. At the same time, we believe that in order to increase the social efficiency of budget expenditures aimed at paying for public sector services, it is expedient in many cases to switch from a mechanism of subsidizing a service provider (organization of non-profit institutions) to subsidizing a service recipient (household) (figure 1).
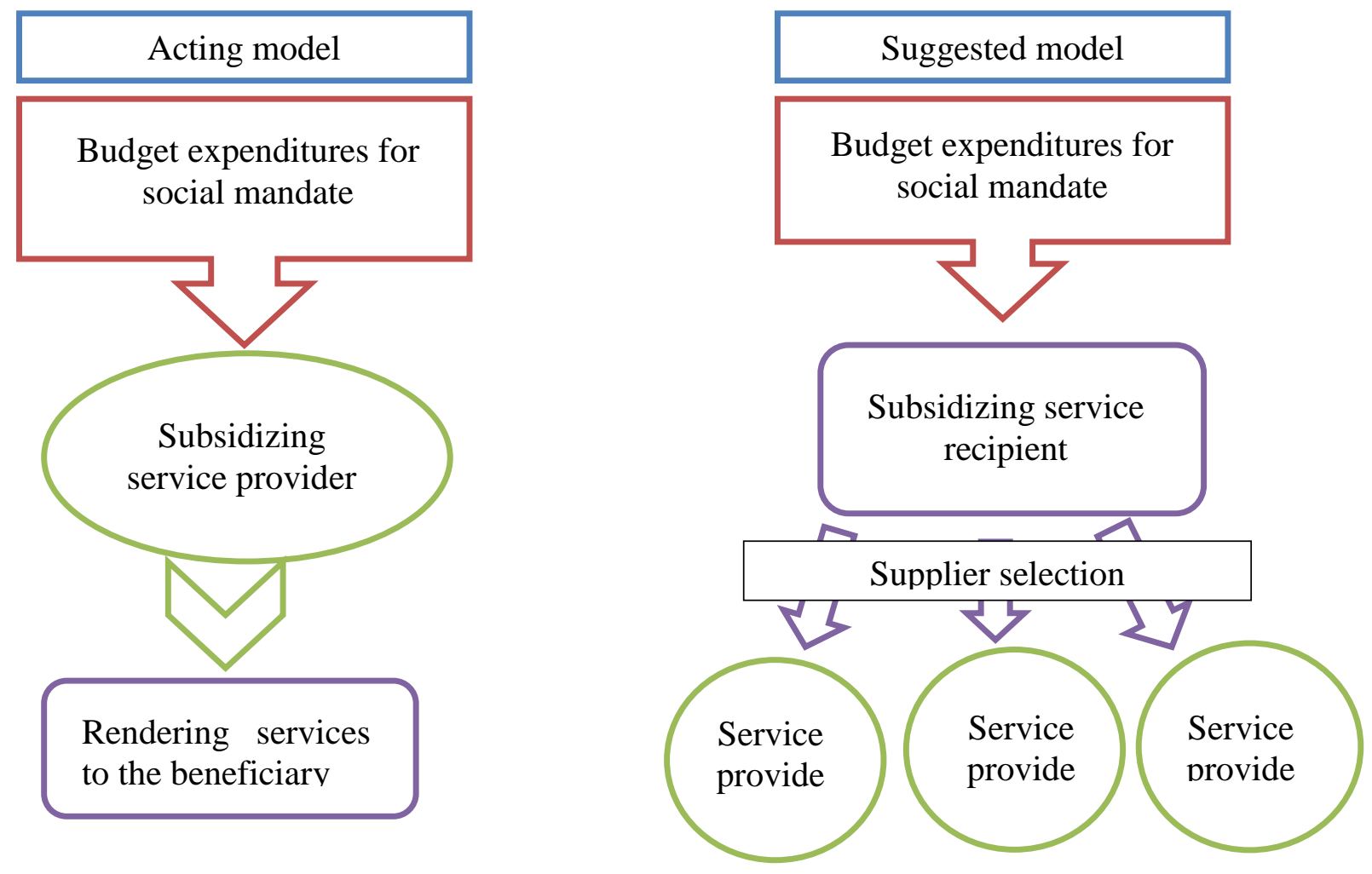

Figure 1. Transformation of the economic mechanism of budget expenditures distribution for the state social order Source: compiled by authors 
This subsidy may take the form of a certificate (voucher or security of any other quality), which is given to the applicant who is legally entitled to a public good, it actually increases his or her income (Makarov, 2018).

The applicant submits a certificate to the organization, and the organization submits the certificate to the state authorities for payment of its value to the organization.

At the same time, the individual has the option of selecting between service providers and will choose the organization that best suits his or her preferences.

\section{Conclusions}

Based on the results of the study, we draw the following conclusions.

Despite some additional transactions, developed mechanism, on the one hand, responds to the interests of the beneficiaries better, and on the other hand, supports more competitive institutions. It forms competition among suppliers of benefits and, finally, optimizes the number of non-commercial institutions among which the more competitive ones survive. As the results of our factor analysis show, it is the social demand from disabled people and pensioners that is one of the driving forces for the non-profit sector development.

Therefore, ultimately, this mechanism increases the efficiency of budget expenditures to support the noncommercial sector, since state social order funds are allocated for the service consumer and are not directly allocated to the non-profit sector.

In addition, the proposed economic mechanism will create an impetus for the social entrepreneurship growth. Under the conditions of limited budget funds, non-profit institutions with considerable experience in providing social services and highly qualified personnel will become more active in offering their services in the market.

As the world experience shows, such institutions often lack marketing programs and experience in doing business, but technical support from the development institutions (universities, business associations, etc.) will allow them to develop activities in the field of social entrepreneurship more efficiently.

In our opinion, social entrepreneurship should become a new idea and efficient practice that will enable experienced non-profit institutions, honest service providers to survive and develop which demonstrates a creative approach to their activities.

\section{References}

Alter, K. 2007. Social enterprise typology. Virtue Ventures LLC. 124 p.

Austin, J., Stevenson, G., Way-Skillern, J. 2010. Social and commercial entrepreneurship: similarities and differences. Bulletin of St. Petersburg University, 3(11), 115-145.

Bowlby, S., Lloyd Evans, S. 2011. Between State and Market: The Non-Profit Workforce in a Changing Local Environment. Social Policy and Society, 10(3), 417-427. https://doi.org/10.1017/S1474746411000133 


\section{ENTREPRENEURSHIP AND SUSTAINABILITY ISSUES}

ISSN 2345-0282 (online) http://jssidoi.org/jesi/

2020 Volume 7 Number 4 (June)

http://doi.org/10.9770/jesi.2020.7.4(14)

Data of the Ministry of National Economy of the Republic of Kazakhstan for 2014-2018. https://economy.gov.kz

Dees, J.G. 2001. The meaning of social entrepreneurship. Center for the Advancement of Social Entrepreneurship, Duke University's Fuqua School of Business. http://www.caseatduke.org/documents/dees_sedef.pdf

Defourny, J. Nyssens, M. 2010. Conceptions of social enterprise and social entrepreneurship in Europe and the United States: convergences and divergences. Journal of Social Entrepreneurship, 1(3), 32-53.

Doherty, B., Haugh, H. 2014. Social Enterprises as Hybrid Organizations: A Review and Research Agenda. International Journal of Management Reviews, 1(4), 223-229.

Franco, M., Belo, M. 2013. Cooperation networks as a mechanism for strengthening territorial competitiveness: The case of the Qualifica Association. World Review of Enterpreneurship Management and Sustainable Development, 9(4), 421-443.

Franco, M., Haase, H. 2017. Collective entrepreneurship: Employees' perceptions of the influence of leadership styles. Journal of Management \& Organization, 23(2), 241-257. https://doi.org/10.1017/jmo.2016.3

Gelashvili, N.N., Zhumanova, B.K.2019. Social Entrepreneurship in the Republic of Kazakhstan: Problems and Development Prospects. Creative Economy, 2, 231-238.

Gramescu, L. 2016. Scaling Social Innovation in Europe: An Overview of Social Enterprise Readiness. Procedia - Social and Behavioral Sciences, 8(14), 218-225.

Gramescu, L. 2016. Scaling Social Innovation in Europe: An Overview of Social Enterprise Readiness. Procedia - Social and Behavioral Sciences, 8, 218-225.

Harvard Center To Study Nonprofit Sector. https://www.exed.hbs.edu/programs/pmno/Pages/hauser-center.aspx

Haugh, H. 2007. New Strategies for a Sustainable Society: The Growing Contribution of Social Entrepreneurship. Business Ethics Quarterly, 17(4), 743-749. https://doi.org/10.5840/beq20071747

Kachko, D.S. 2017. Social entrepreneurship: problems and development prospects in Russia. Russian Entrepreneurship, 3(18), $215-221$. https://doi.org/10.18334/rp.18.3.37286

Kowo, S. A., Adenuga, O. A. O.; Sabitu, O.O. 2019. The role of SMEs development on poverty alleviation in Nigeria. Insights into Regional Development 1(3): 214-226. https://doi.org/10.9770/ird.2019.1.3(3)

Kuzmin, A.V., Yegerev, S.V. 2009. Evaluation of the effectiveness of interaction between business, government and the non-profit sector in the system of intersectoral social partnership. Russian Journal of Entrepreneurship, 5(10), 18-24. https://creativeconomy.ru/lib/5284

Labor Code the Republic of Kazakhstan. 2016. https://online.zakon.kz/document/?doc_id=38910832\#pos=44;-101

Lance, R. 2017. Changing the System: Compensatory versus Transformative Social Entrepreneurship. Journal of Social Entrepreneurship, 4(15), 125-138. https://doi.org/10.1080/19420676.2017.1408671

Lance, R. 2017. Newey. Changing the System: Compensatory versus Transformative Social Entrepreneurship. Journal of Social Entrepreneurship, 4, 125-138. https://doi.org/10.1080/19420676.2017.1408671

Law of the Republic of Kazakhstan dated January 16, 2001 "On Non-profit Institutions", No. 142-II.

Law of the Republic of Kazakhstan. 2001. No. 142-II On non-profit organizations (as amended and supplemented as of December 26, 2019). https://www.zakon.kz

Law of the Republic of Kazakhstan. 2005. No. 30 On compulsory insurance of an employee against accidents in the performance of his labor (official) duties. https://www.zakon.kz 


\section{ENTREPRENEURSHIP AND SUSTAINABILITY ISSUES}

ISSN 2345-0282 (online) http://jssidoi.org/jesi/

2020 Volume 7 Number 4 (June)

http://doi.org/10.9770/jesi.2020.7.4(14)

Law of the Republic of Kazakhstan. 2010. No. 274-IV On Protection of Consumer Rights. https://www.zakon.kz

Law of the Republic of Kazakhstan. 2018. No. 169-VI On the Protection of Children from Information Harmful to Their Health and Development. https://www.zakon.kz

Lombardo, S. 2013. Some Reflections on Freedom of Establishment of Nonprofit Entities in the European Union. European Business Organization Law Review, 14(2), 225-263.

Makarov, M. E. 2018. Social voucher as a tool to improve the efficiency of the public services in the social sphere. Young scientist, 46, 374-376.

Martin, R.L., Osberg, S. 2007. Social Entrepreneurship: the Case for Definition. Stanford Social Innovation Review, 4(12), $23-29$.

Mersiyanova, I. V. 2017. NPO as a social service provider: Verification of weaknesses, Issues of state and municipal governance, 2, 83105 .

Moskovskaya, A., Soboleva, I. 2016. Social entrepreneurship in the system of social policy: world experience and prospects of Russia. Problems of Forecasting, 6(12), 94-114.

National accounts of the Republic of Kazakhstan, 2010-2014, 2012-2017. Astana: Committee on Statistics of the Ministry of National Economy of the Republic of Kazakhstan, 2019. http://stat.gov.kz/

Nesterenko, Y., Plyukhina, A. 2017. The development of social entrepreneurship in the Russian economy. M.: Creative economy, 154 p. https://doi.org/10.18334/9785912921698

Pritvorova, T.P., Ayaganova, M.P. 2017. The Nonprofit Sector as a Basis for Social Entrepreneurship in Kazakhstan: Potential and Models. Revista Espasios, 38(49), 10.

Rasheda, L. 2018. Re-Conceptualizing Social Value: Applying the Capability Approach in Social Enterprise Research. Journal of Social Entrepreneurship, 9 (2), 79-93. https://doi.org/10.1080/19420676.2018.1430607

Rasheda, L. 2018. Re-Conceptualizing Social Value: Applying the Capability Approach in Social Enterprise Research. Journal of Social Entrepreneurship, 9, 2, 79-93. https://doi.org/10.1080/19420676.2018.1430607

Rozhdestvenskaya, N. 2017. Estimation of the nonprofit institutions efficiency, social entrepreneurship and civic initiatives projects. St. Petersburg: Polytechnic University, 168.

Rubinstein, A. Ya. 2009. "To the issue of expanding the "pure theory of public expenditure". Moscow: IE RAS.

Salamon, L.M., Anheier, H.K. and other. 2014. Global Civil Society. Dimensions of the Nonprofit Sector. The Johns Hopkins Center for Civil Society Studies. Baltimore, 4, 10.

Schlichter, A. 2016. The U.S. non-profit sector: resources, areas of activity and effectiveness. DOE and MoD, 8, 89-97.

Sen, A. 2016. The idea of justice. Moscow: Gaydar Institute.

Singgalen, Y.A., Sasongko, G., Wiloso, P.G. 2019. Community participation in regional tourism development: a case study in North Halmahera Regency - Indonesia. Insights into Regional Development, 1(4), 318-332. https://doi.org/10.9770/ird.2019.1.4(3)

Statistics committee Ministry of National Economy of the Republic of Kazakhstan http://www.fao.org/giews/food-prices/datapartners/detail/en/c/421427/

Thompson, J., Doherty, B. 2012. The diverse world of social enterprise: a collection of social enterprise stories. International Journal of Social Economics, 33, 5/6, 361-375. 


\section{ENTREPRENEURSHIP AND SUSTAINABILITY ISSUES}

ISSN 2345-0282 (online) http://jssidoi.org/jesi/

2020 Volume 7 Number 4 (June)

http://doi.org/10.9770/jesi.2020.7.4(14)

Vigliarolo, F. 2020. Economic phenomenology: fundamentals, principles and definition. Insights into Regional Development, 2(1), 418429. http://doi.org/10.9770/IRD.2020.2.1(2)

Yeliseeva, I. I., Yuzbashev, M. M. 2012. General Theory of Statistics. Textbook. Moscow: Finances and statistics.

\section{Acknowledgements}

This research was supported by the project, which has received funding from the Science Committee of the Ministry of Education and Science of the Republic of Kazakhstan Social entrepreneurship in modern economic systems: concept, typology, development mechanisms in Kazakhstan. Grant Agreement Number AP05130260

Bagdat SPANOVA is PhD student of Karaganda Economic University of Kazpotrebsoyuz, Karaganda, Kazakhstan. Research interests: economics and finance, entrepreneurship, investment, innovation, logistics.

ORCID ID: orcid.org/0000-0002-7226-3796

Gulmira NAKIPOVA is Doctor of Economic Sciences, Professor of Karaganda Economic University of Kazpotrebsoyuz, Karaganda, Kazakhstan. Research interests: economics and finance, entrepreneurship, investment, innovation, logistics, marketing.

ORCID ID: orcid.org/0000-0001-6754-246X

Galina PESTUNOVA is Candidate of Economic Sciences, Associate professor of D.Serikbayev East Kazakhstan State Technical University, Ust-Kamenogorsk, Kazakhstan. Research interests: economy, management, innovations, human resources.

ORCID ID: orcid.org/0000-0001-8772-536X

Aigul MUKATAY is Candidate of Economic Sciences, Associate professor of D.Serikbayev East Kazakhstan State Technical University, Ust-Kamenogorsk, Kazakhstan. Research interests: economy, management, innovations, human resources.

ORCID ID: orcid.org/0000-0003-3830-0247

Baldyrgan JAZYKBAYEVA is PhD, Associate professor of Karaganda Economic University of Kazpotrebsoyuz, Karaganda, Kazakhstan. Research interests: economics and finance, entrepreneurship, investment, innovation, logistics. ORCID ID: orcid.org/0000-0003-0738-2526 